\title{
Invigorasi Benih Kelor (Moringa oleifera) dengan Berbagai Konsentrasi dan Jenis ZPT Terhadap Pertumbuhan dan Bobot Biomasa
}

\section{Invigoration of Moringa Seed (Moringa oleifera) Used Consentration Level and Types of Hormones on Growth and Weight Biomass}

\author{
Yanu Andria Sucianto ${ }^{1 *}$, Sutarno $^{2}$, Syaiful Anwar ${ }^{2}$ \\ ${ }^{1}$ Program Studi Agroteknologi, Departemen Pertanian, Fakultas Peternakan dan Pertanian \\ Universitas Diponegoro \\ ${ }^{2}$ Departemen Pertanian, Fakultas Peternakan dan Pertanian, Universitas Diponegoro \\ *E-mail:yanuandria@gmail.com
}

Diterima 9 April 2019 / Disetujui 2 Agustus 2019

\begin{abstract}
ABSTRAK
Penelitian ini bertujuan untuk mengetahui perlakuan invigorasi dengan menggunakan zat pengatur tumbuh terhadap viabilitas benih kelor setelah mengalami penyimpanan dan mengetahui konsentrasi yang tepat untuk invigorasi pada benih kelor. Penelitian menggunakan Rancangan Acak Lengkap Faktorial 3x2 dengan 5 kali ulangan. Faktor pertama yaitu konsentrasi ZPT (zat pengatur tumbuh) yang terdiri atas 3 taraf yaitu D0: 0 ppm, D1: 50 pm, D2:100 ppm. Faktor kedua yaitu jenis zat pengatur tumbuh yang terdiri atas 2 jenis yaitu M1: (Giberelin Acid) $\mathrm{GA}_{3}$, M2: (Naphthalene Acetic Acid) NAA. Parameter yang diamati dalam penelitian ini terbagi atas parameter perkecambahan benih dan parameter pertumbuhan bibit. Paremeter perkecambahan yaitu daya kecambah, potensi tumbuh maksimum, tinggi kecambah, panjang akar kecambah, kecepatan berkecambahan dan parameter pertumbuhan bibit yaitu jumlah daun, diameter batang, tinggi tanaman, bobot biomasa basah dan bobot biomasa kering. Data dianalisis ragam (uji F) dan dilanjut dengan Duncan's Multiple Range Test (DMRT). Hasil penelitian menunjukkan bahwa penggunaan hormon $\mathrm{GA}_{3}$ pada benih kelor lebih responsif dari penggunaan hormon NAA pada hampir semua parameter yang diamati.
\end{abstract}

Kata kunci : kelor, zat pengatur tumbuh, pertumbuhan

\begin{abstract}
This reseach aims to determine the invigoration treatment by using growth regulators on the viability of Moringa seeds after storing and knowing the appropriate concentration for invisibility on Moringa seeds. The study used Factorial Completely Randomized Design 3x2 with 5 replications. The first factor is the concentration of growth regulator which consists of 3 levels, namely D0: 0 ppm, D1: 50 ppm, D2: 100 ppm. The second factor is the type of growth regulator which consists of 2 types, namely M1: (Giberelin Acid) GA3, M2: (Naphthalene Acetic Acid) NAA. The parameters observed in this study were divided into seed germination parameters and seed growth parameters. Germination parameters were sprout power, maximum growth potential, seedling height, sprout root length, germination rate and seed growth parameters, namely number of leaves, stem diameter, plant height, weight of wet biomass and dry biomass weight. Data were analyzed for variance (F test) and continued with Duncan's Multiple Range Test (DMRT). The results showed that the use of GA3 hormone in moringa seeds was more responsive than the use of NAA hormones in almost all observed parameters
\end{abstract}

Keywords: Moriga oleifera, plant growth regulator, growth

\section{PENDAHULUAN}

Kelor adalah tumbuhan yang berasal dari suku moringaceae yang berasal dari India. Kelor memiliki daun berbentuk bulat telur dengan ukuran kecil-kecil tersusun majemuk dalam satu tangkai. Tanaman kelor merupakan salah satu tanaman ajaib, tidak hanya sebagai sumber 
pangan, pengobatan, dan makanan ternak, tanaman ini juga dapat digunakan sebagai sumber energi alternatif bahan bakar biodiesel yang ramah lingkungan (Nurcahyani, 2014). Daun kelor kering memiliki kandungan kalsium 3,65 \%, fosfor $0,30 \%$, magnesium $0,50 \%$, potasium $1,5 \%$, sodium $0,164 \%$, sulfur $0,63 \%$, zink $31 \mathrm{mg} / \mathrm{kg}$, mangan 86,5 mg/kg dan zat besi $363 \mathrm{mg} / \mathrm{kg}$ (Moyo et al., 2011).).

Budidaya kelor yang masih rendah dan kurangnya pengetahuan masyarakat tentang manfaat tanaman membuat kelor belum diminati dan dibudidayakan oleh masyarakat, padahal tanaman kelor termasuk tanaman yang tahan terhadap cekaman kekeringan (Sunawira, 2012). Kelor yang ditanam dengan benih mempunyai kemampuan produksi biomassa yang tinggi yaitu mencapai 4,2-8,3 ton bahan kering/ha pada interval pemotongan 45 hari (Foild et al., 2007). Biji Kelor berkecambah 4-12 hari setelah tanam, apabila biji tidak berkecambah setelah dua minggu, harus diganti karena benih tidak akan tumbuh. Tanaman Kelor muda dipindah ke polybag ketika tinggi tanaman sekitar $5 \mathrm{~cm}$ dan pastikan bahwa akar tanaman tidak rusak (Krisnadi, 2015). Permasalahan pada benih kelor yaitu mengalami deteriorasi yang tinggi setelah mengalami penyimpanan sehingga perlu perlakuan yang dapat meningkatkan perkecambahan benih. Salah satu cara yang dapat digunakan yaitu menggunakan invigorasi. Invigorasi benih merupakan upaya perbaikan fisiologis dan biokimia yang berhubungan dengan kecepatan, keserempakan berkecambah, perbaikan sertapeningkatan kemampuan berkecambah benih. Invigorasi benih dilakukan untuk meningkatkan vigor benih yang rendah akibat penyimpanan (Saryoko, 2011).

Invigorasi benih dapat dilakukan dengan menggunakan media matriks rendah (matriconditioning), penggunaan zat pengatur tumbuhan (ZPT), agen hayati, priming, osmoconditioning, moisturizing (Sutariati et al., 2014). Invigorasi benih menggunakan ZPT biasanya dilakukan dengan melakukan perendaman benih pada larutan ZPT. Invigorasi menggunakan ZPT dapat meningkatkan aktivitas perombakan bahan organik dalam benih sehingga cadangan makanan untuk perkecambahan tersedia dan dapat digunakan untuk perkembangan embrio, selain itu embrio dapat lebih cepat memanfaatkan faktor pendukung perkecambahan seperti air dan oksigen (Adelina dan maemunah, 2009).

Penelitian ini bertujuan untuk mengetahui efek perlakuan invigorasi dengan ZPT terhadap viabilitas benih kelor setelah mengalami penyimpanan lebih dari tiga bulan, mengetahui berapa konsentrasi ZPT yang cocok untuk perlakuan invigorasi pada benih kelor serta mengetahui interaksi antara jenis ZPT yang digunakan dengan konsentrasi yang diberikan.

\section{METODE PENELITIAN}

\section{Bahan dan alat}

Bahan yang digunakan dalam penelitian yaitu benih kelor dari PT. Sekar Utami Toga, aquades, etanol 96\%, tanah, pupuk kandang sapi, arang sekam, fungisida dithane M-45, Gibberelic Acid (GA), Naphthalene Acetic Acid (NAA). Alat yang digunakan dalam penelitian yaitu gelas ukur, pipet, gelas plastik, mika plastik, botol plastik, sprayer, jangka sorong, mistar, timbangan analitik,tisu, polybag, cangkul dan alat tulis.

\section{Metode}

Persiapan bahan berupa pemilihan benih kelor yang sudah mengalami penyimpanan lebih dari tiga bulan kemudian disortir sesuai warna dan ukurannya kemudian benih direndam dengan fugisida selama tiga jam dan ditiriskan selama 12 jam. Membuat larutan dengan konsetrasi 0, 50 dan 100 ppm untuk hormon $\mathrm{GA}_{3}$ dan NAA. Perlakuan 0 ppm atau tanpa perlakuan hanya menggunakan aquades. Benih direndam selama 18 jam pada larutan. Penyemaian dilakukan dengan menggunakan metode UKDK (Uji Kecambah Diantara Kertas). Pengamatan parameter perkecambahan dilakukan setiap hari sampai hari ke tujuh. Persiapan pemindahan ke polybag, disiapkan media tanam yang sudah diberi dengan 2 gram fungisida dithane M-45 pada setiap polybag. Pemeliharaan tanaman meliputi penyiraman, 
penyiangan, penyulaman serta pengendalian hama dan penyakit. Pengamatan parameter tinggi tanaman diamati setiap minggu dengan cara mengukur dari pangkal batang sampai titik tumbuh. Jumlah daun diamati setiap minggu dengan cara menghitung total jumlah daun yang terdapat pada setiap tanaman. Diameter tanaman diukur setiap minggu pada pangkal batang dengan menggunakan jangka sorong. Biomasa tanaman diukur ketika panen dengan cara dioven pada suhu $105^{\circ} \mathrm{C}$ selama 24 jam. Pengamatan dilakukan sampai tanaman berumur 50 hari.

\section{Rancangan Percobaan dan Analisis Data}

Penelitian ini menggunakan Rancangan Acak Lengkap (RAL) pola faktorial 3x2 dengan 5 kali ulangan. Faktor pertama yaitu konsentrasi ZPT yang terdiri atas 3 taraf yaitu D0: 0 ppm, D1: $50 \mathrm{pm}, \mathrm{D} 2: 100 \mathrm{ppm}$. Faktor kedua yaitu jenis ZPT terdiri atas 2 taraf yaitu M1: GA 3 , M2: NAA. Data yang diperoleh kemudian dianalisis ragam (Uji F) dan dilanjutkan dengan uji jarak berganda Duncan (Duncan's Multiple Range Test $=$ DMRT) pada taraf 5\% $(\mathrm{P}<0,05)$.

\section{HASIL DAN PEMBAHASAN}

Hasil analisis ragam menunjukkan bahwa konsentrasi ZPT yang diberikan berpengaruh nyata $(\mathrm{P}<0,05)$ terhadap daya kecambah benih kelor. Daya kecambah benih kelor pada konsentrasi yang berbeda dengan berbagai jenis ZPT dapat dilihat pada Tabel 1.Hasil DMRT pada Tabel 1 menunjukkan bahwa pada penambahan konsentrasi $\mathrm{GA}_{3}$ dan NAA dari 0 ppm sampai 50 ppm dapat meningkatkan daya kecambah, tetapi penambahan konsentrasi menjadi 100 ppm terjadi penurunan daya kecambah. Pada konsentrasi 50 ppm pada perlakuan $\mathrm{GA}_{3}$ berpengaruh nyata terhadap daya kecambah benih kelor, sedangkan perlakuan $\mathrm{GA}_{3} 0 \mathrm{ppm}, \mathrm{GA}_{3} 100$ ppm, NAA 0 ppm, NAA 50 ppm dan NAA 100 ppm tidak berpengaruh nyata terhadap daya kecambah benih kelor. Daya kecambah tertingggi yaitu pada perlakuan $\mathrm{GA}_{3} 50$ ppm sebesar $84 \%$ sedangkan daya kecambah terendah terdapat pada perlakuan NAA 0 ppm sebesar 72\%. Daya kecambah benih sangat terkait dengan laju imbisisi benih, semakin banyak benih dapat menyerap air maka dapat memicu terjadinya reaksi enzimatik yang nantinya akan mengurai cadangan makanan yang berada didalam benih. Menurut Weiss dan Ori (2007) giberelin dapat meningkatkan laju imbisisi benih sehingga dapat mengurai cadangan makanan yang digunakan sebagai sumber energi untuk pertumbuhan dalam waktu yang lebih cepat dan serentak.Hal tersebut sesuai dengan pendapat Mudyantini (2011) giberelin dapat melenturkan dinding sel dan menaikkan tekanan osmotik sehingga sel menjadi lebih besar dan meningkatkan terjadinya pembelahan kulit benih.

Tabel 1. Daya Kecambah Benih Kelor (\%) di Hari ke-7 pada Aplikasi Jenis ZPT dan Konsentrasi ZPT yang berbeda.

\begin{tabular}{ccccc}
\hline \multirow{2}{*}{ ZPT } & \multicolumn{3}{c}{ Konsentrasi ZPT $(\mathrm{ppm})$} & \multirow{2}{*}{ Rata-Rata } \\
\cline { 2 - 4 } & $0(\mathrm{D} 0)$ & $50(\mathrm{D} 1)$ & $100(\mathrm{D} 2)$ & $77^{\mathrm{b}}$ \\
\hline M1 $\left(\mathrm{GA}_{3}\right)$ & $72^{\mathrm{b}}$ & $84^{\mathrm{a}}$ & $77^{\mathrm{a}}$ \\
M2 (NAA) & $72^{\mathrm{b}}$ & $77^{\mathrm{b}}$ & $74^{\mathrm{b}}$ & $74^{\mathrm{b}}$ \\
\hline Rerata & $72^{\mathrm{b}}$ & $80^{\mathrm{a}}$ & $76^{\mathrm{b}}$ & 76 \\
\hline
\end{tabular}

Keterangan: Superskrip yang berbeda pada baris rerata, kolom rerata dan matrik interaksi menujukkan perbedaan yang nyata $(\mathrm{P}<0,05)$

Hasil analisis ragam menunjukkan bahwa konsentrasi $\mathrm{GA}_{3}$ yang berbeda berpengaruh nyata $(\mathrm{P}<0,05)$ terhadap potensi tumbuh maksimal benih kelor. Potensi tuumbuh maksimal benih kelor pada konsentrasi yang berbeda dengan berbagai jenis
ZPT dapat dilihat pada Tabel 2. Hasil DMRT pada Tabel 2 menunjukkan bahwa dengan penambahan konsentrasi $\mathrm{GA}_{3}$ dari 0 ppm sampai 50 ppm dapat meningkatkan potensi tumbuh maksimal, tetapi penambahan konsentrasi menjadi 100 ppm terjadi 
penurunan potensi tumbuh maksimal. Pada konsentrasi 50 ppm dengan perlakuan $\mathrm{GA}_{3}$ berbeda nyata dengan seluruh perlakuan, sedangkan pada perlakuan $\mathrm{GA}_{3} 0 \mathrm{ppm}\left(\right.$ ), $\mathrm{GA}_{3} 100$ ppm (), NAA 0 ppm, NAA 50 ppm dan NAA 100 ppm tidak saling berbeda nyata. Perlakuan $\mathrm{GA}_{3} 50$ ppm memiliki potensi tumbuh tertinggi sebesar $88 \%$ sedangkan perlakuan NAA 0 ppm memiliki potensi tumbuh paling rendah dengan $77 \%$. Potensi tumbuh pada benih berkaitan dengan jumlah benih yang berkecambah secara keseluruhan baik yang tumbuh secara normal maupun tidak normal. Potensi tumbuh pada benih dipengaruhi oleh hilangnya hambatan benih dalam berkecambah yaitu jaringan disekitar radikula dan kerasnya kulit benih, hilangnya hambatan pada benih tersebut bisa dipengaruhi oleh masuknya giberelin kedalam benih yang disebabkan oleh tekanan osmotik. Hal tersebut sesuai dengan pendapat Polhaupessy (2014) yang menyatakan bahwa giberelin selama perkecambahan benih dapat meningkatkan potensi tumbuh dari embrio, sebagai promotor perkecambahan dan mengatasi hambatan mekanik oleh lapisan penutup benih karena terdapatnya jaringan di sekeliling radikula. Menurut Tjokrowardojo et al., (2009) faktor yang dapat mempengaruhi potensi tumbuh dari benih yaitu enzim amilase yang diaktifkan oleh giberelin sehingga dapat memberikan energi untuk perkembangan radikula yang akan memecah endosperm, kulit biji atau kulit buah yang menjadi faktor pembatas perkecambahan.

Tabel 2. Potensi Tumbuh Maksimal Benih Kelor (\%) di Hari ke-7 pada Aplikasi Jenis ZPT dan Konsentrasi ZPT yang berbeda.

\begin{tabular}{ccccc}
\hline \multirow{2}{*}{ ZPT } & \multicolumn{3}{c}{ Konsentrasi ZPT $(\mathrm{ppm})$} & \multirow{2}{*}{ Rata-Rata } \\
\cline { 2 - 4 } & $0(\mathrm{D} 0)$ & $50(\mathrm{D} 1)$ & $100(\mathrm{D} 2)$ & $82^{\mathrm{a}}$ \\
\hline M1 $\left(\mathrm{GA}_{3}\right)$ & $77^{\mathrm{b}}$ & $88^{\mathrm{a}}$ & $82^{\mathrm{b}}$ & $79^{\mathrm{a}}$ \\
\hline M2 (NAA) & $77^{\mathrm{b}}$ & $80^{\mathrm{b}}$ & $80^{\mathrm{b}}$ & 80 \\
\hline Rerata & $77^{\mathrm{b}}$ & $84^{\mathrm{a}}$ & $81^{\mathrm{a}}$ & 8 \\
\hline
\end{tabular}

Keterangan: Superskrip yang berbeda pada baris rerata, kolom rerata dan matrik interaksi menujukkan perbedaan yang nyata $(\mathrm{P}<0,05)$

Hasil analisis ragam menunjukkan bahwa konsentrasi $\mathrm{GA}_{3}$ dan NAA yang berbeda berpengaruh nyata $(\mathrm{P}<0,05)$ terhadap kecepatan berkecambah benih kelor. Kecepatan berkecambah benih kelor pada konsentrasi yang berbeda dengan berbagai jenis ZPT dapat dilihat pada Tabel 3.

Tabel 3. Kecepatan Berkecambah Benih Kelor (\%/etmal) di Hari ke-7 pada Aplikasi Jenis ZPT dan Konsentrasi ZPT yang berbeda.

\begin{tabular}{ccccc}
\hline \multirow{2}{*}{ ZPT } & \multicolumn{3}{c}{ Konsentrasi ZPT $(\mathrm{ppm})$} & \multirow{2}{*}{ Rata-Rata } \\
\hline M1 (GA $)$ & $0(\mathrm{D} 0)$ & $50(\mathrm{D} 1)$ & $100(\mathrm{D} 2)$ & \\
\hline M2 (NAA) & $1,003^{\mathrm{c}}$ & $1,483^{\mathrm{a}}$ & $1,232^{\mathrm{b}}$ & $1,239^{\mathrm{a}}$ \\
\hline Rerata & $1,008^{\mathrm{c}}$ & $1,276^{\mathrm{b}}$ & $1,206^{\mathrm{b}}$ & $1,163^{\mathrm{b}}$ \\
\hline $1,005^{\mathrm{c}}$ & $1,379^{\mathrm{a}}$ & $1,219^{\mathrm{b}}$ & 1,201 \\
\hline
\end{tabular}

Keterangan: Superskrip yang berbeda pada baris rerata, kolom rerata dan matrik interaksi menujukkan perbedaan yang nyata $(\mathrm{P}<0,05)$

Hasil DMRT pada tabel 3 menunjukkan bahwa konsentrasi 0 ppm pada perlakuan $\mathrm{GA}_{3}$ berbeda nyata dengan perlakuan $50 \mathrm{ppm} \mathrm{GA}_{3}$. Perlakuan 50 ppm $\mathrm{GA}_{3}$ berbeda nyata dengan perlakuan konsentrasi 100 ppm $\mathrm{GA}_{3}$. Konsentrasi 0 ppm pada NAA tidak berbeda nyata dengan konsentrasi 0 ppm $\mathrm{GA}_{3}$. Perlakuan 50 ppm NAA berbeda nyata dengan perlakuan 0 ppm NAA tetapi tidak berbeda nyata dengan perlakuan 100 ppm NAA. Aplikasi konsentrasi 0 ppm $\mathrm{GA}_{3}$ dan NAA tidak meningkatkan kecepatan berkecambah benih kelor. Konsentrasi 0 ppm $\mathrm{GA}_{3}$ dan NAA 
memiliki kecepatan berkecambah terendah yaitu sebesar 1,003 \%/etmal dan 1,008 \%/etmal. Konsentrasi $\mathrm{GA}_{3} 50 \mathrm{ppm}$ memberikan hasil tertinggi dibanding dengan perlakuan lainnnya dalam meningkatkan kecepatan kecambah pada benih kelor yaitu sebesar 1,483 \%/etmal. Kecepatan berkecambah pada benih berkaitan erat dengan jumlah air yang diserap oleh benih, semakin banyak air yang dapat diserap maka kecepatan benih dalam berkecambah juga akan semakin tinggi. Giberelin yang diberikan dengan konsentrasi yang sesuai bisa mempecepat perkecambahan karena giberelin membantu trasnskripsi gen penanda enzim hidrolitik yang berperan dalam hidrolisis pati dan protein sebagi sumber energi untuk perkecambahan. Hal tersebut sesuai dengan pendapat Sari et al., (2014) yang menyatakan bahwa giberelin membantu dalam mendorong proses penyerapan air oleh benih sehingga dapat mempercepat perkecambahan. Menurut Weiss dan Ori (2007) perendaman biji dengan waktu yang lebih lama meningkatkan giberelin yang dapat diserap oleh benih sehingga dapat mempercepat perkecambahan.

Hasil analisis ragam menunjukkan bahwa konsentrasi $\mathrm{GA}_{3}$ dan NAA yang berbeda berpengaruh nyata $(\mathrm{P}<0,05)$ terhadap jumlah daun kelor.Jumlah daun kelor pada konsentrasi yang berbeda dengan berbagai jenis ZPT dapat dilihat pada Tabel 4.

Tabel 4. Jumlah Daun Kelor (helai) pada Minggu ke-7 pada Aplikasi Jenis ZPT dan Konsentrasi ZPT yang berbeda.

\begin{tabular}{ccccc}
\hline \multirow{2}{*}{ ZPT } & \multicolumn{3}{c}{ Konsentrasi ZPT $(\mathrm{ppm})$} & \multirow{2}{*}{ Rata-Rata } \\
\cline { 2 - 4 } & $0(\mathrm{D} 0)$ & $50(\mathrm{D} 1)$ & $100(\mathrm{D} 2)$ & \\
\hline M1 $\left(\mathrm{GA}_{3}\right)$ & $43^{\mathrm{c}}$ & $60^{\mathrm{a}}$ & $59^{\mathrm{a}}$ & $54^{\mathrm{a}}$ \\
M2 (NAA) & $44^{\mathrm{c}}$ & $60^{\mathrm{a}}$ & $55^{\mathrm{b}}$ & $53^{\mathrm{a}}$ \\
\hline Rerata & $44^{\mathrm{c}}$ & $60^{\mathrm{a}}$ & $57^{\mathrm{b}}$ & 53 \\
\hline
\end{tabular}

Keterangan: Superskrip yang berbeda pada baris rerata, kolom rerata dan matrik interaksi menujukkan perbedaan yang nyata $(\mathrm{P}<0,05)$

Hasil DMRT pada Tabel 4 menunjukkan bahwa konsentrasi 0 ppm pada perlakuan $\mathrm{GA}_{3}$ berbeda nyata dengan perlakuan 50 ppm $\mathrm{GA}_{3}$. Perlakuan 50 ppm $\mathrm{GA}_{3}$ tidak berbeda nyata dengan perlakuan konsentrasi 100 ppm $\mathrm{GA}_{3}$. Konsentrasi 0 ppm pada NAA tidak berbeda nyata dengan konsentrasi 0 ppm GA 3 . Perlakuan 50 ppm NAA berbeda nyata dengan perlakuan 0 ppm NAA dan perlakuan 100 ppm NAA. Perlakuan 50 ppm $\mathrm{GA}_{3}$ tidak berbeda nyata dengan perlakuan $50 \mathrm{ppm}$ NAA. Konsentrasi 0 ppm GA $\mathrm{G}_{3}$ dan NAA memiliki jumlah daun terendah yaitu sebesar 43 dan 44 helai. Konsentrasi $\mathrm{GA}_{3}$ dan NAA 50 ppm memberikan hasil tertinggi dibanding dengan perlakuan lainnnya dalam meningkatkan pertambahan jumlah daun pada kelor yaitu sebesar 60 helai. Jumlah daun pada tanaman berkaitan dengan aktifitas fotosintesis dan penyerapan air oleh tanaman. Auksin dapat meningkatkan distribusi dan penyerapan air pada tanaman dan aktivitas fotosintesis sehingga dapat meingkatkan proses perkembangan jaringan. Hal tersebut sesuai dengan pendapat Marzuki et al., (2008) yang menyatakan bahwa penambahan auksin ke dalam tanaman dapat meningkatkan konsentrasi giberelin dan auksin yang terdapat didalam jaringan tanaman. Menurut Lestari (2011) penambahan auksin ke dalam media tanam dapat meningkatkan konsentrasi zat pengatur tumbuh endogen di dalam sel, sehingga menjadi faktor pemicu dalam proses tumbuh dan perkembangan jaringan tanaman.

Hasil analisis ragam menunjukkan bahwa konsentrasi $\mathrm{GA}_{3}$ dan NAA yang berbeda berpengaruh nyata $(\mathrm{P}<0,05)$ terhadap biomasa kering tanaman kelor. Biomasa kering tanaman kelor pada konsentrasi yang berbeda dengan berbagai jenis ZPT dapat dilihat pada Tabel 5 Hasil DMRT pada tabel 5 menunjukkan bahwa konsentrasi 0 ppm pada perlakuan $\mathrm{GA}_{3}$ berbeda nyata dengan perlakuan $50 \mathrm{ppm} \mathrm{GA}_{3}$. Perlakuan 50 ppm $\mathrm{GA}_{3}$ berbeda nyata dengan perlakuan 100 ppm $\mathrm{GA}_{3}$. Konsentrasi 0 ppm pada NAA tidak 
berbeda nyata dengan konsentrasi 0 ppm $\mathrm{GA}_{3}$. Perlakuan 50 ppm NAA berbeda nyata dengan perlakuan 0 ppm NAA. Perlakuan 50 ppm NAA berbeda nyata dengan perlakuan 100 ppm NAA. Konsentrasi 0 ppm $\mathrm{GA}_{3}$ memiliki produksi biomasa basah terendah yaitu sebesar 211 g/tanaman. Konsentrasi $\mathrm{GA}_{3} 50$ ppm memberikan hasil tertinggi dibanding dengan perlakuan lainnnya dalam meningkatkan produksi biomasa basah pada tanaman kelor yaitu sebesar 172 g/tanaman. Produksi biomasa pada tanaman berbanding lurus dengan meningkatnya umur tanaman, semakin tua tanaman maka produksi biomasa yang dihasilkan juga akan semakin tinggi.
Selain disebabkan karena umur tanaman, kecepatan pertumbuhan tanaman dalam pembentukan daun dan cabang juga dapat menigkatkan produksi biomasa. Pemberian giberelin dapat meningkatkan kecepatan pertumbuhan tanaman. Hal tersebut sesuai dengan pendapat Sari et al., (2014) menyatakan bahwa giberelin menyebabkan peningkatan perpanjangan ruas dan meningkatkan tinggi tanaman sehingga bobot kering tanaman meningkat. Menurut Mudyantini (2011) giberelin berperan dalam pembentangan dan pembelahan sel, pemecahan dormansi tunas, pertumbuhan dan perpanjangan batang.

Tabel 5. Biomasa Kering Tanaman Kelor (g) di Minggu ke-7 pada Aplikasi Jenis ZPT dan Konsentrasi ZPT yang berbeda.

\begin{tabular}{ccccc}
\hline \multirow{2}{*}{ ZPT } & \multicolumn{3}{c}{ Konsentrasi ZPT $(\mathrm{ppm})$} & \multirow{2}{*}{ Rata-Rata } \\
\cline { 2 - 4 } & $0(\mathrm{D} 0)$ & $50(\mathrm{D} 1)$ & $100(\mathrm{D} 2)$ & \\
\hline M1 $\left(\mathrm{GA}_{3}\right)$ & $121^{\mathrm{d}}$ & $172^{\mathrm{a}}$ & $156^{\mathrm{b}}$ & $150^{\mathrm{a}}$ \\
M2 (NAA) & $125^{\mathrm{d}}$ & $166^{\mathrm{a}}$ & $145^{\mathrm{c}}$ & $146^{\mathrm{a}}$ \\
\hline Rerata & $123^{\mathrm{c}}$ & $169^{\mathrm{a}}$ & $150 \mathrm{~b}$ & 148 \\
\hline
\end{tabular}

Keterangan: Superskrip yang berbeda pada baris rerata, kolom rerata dan matrik interaksi menujukkan perbedaan yang nyata $(\mathrm{P}<0,05)$

\section{KESIMPULAN}

Berdasarkan hasil penelitian dapat disimpukan bahwa pada proses perkecambahan konsentrasi $\mathrm{GA}_{3}$ sampai konsentrasi $50 \mathrm{ppm}$ meningkatkan daya kecambah, potensi tumbuh maksimal dan kecepatan berkecambah akan tetapi ketika konsentrasi ditingkatkan sampai 100 ppm terjadi penurunan. Penggunaan hormon $\mathrm{GA}_{3}$ pada invigorasi benih kelor lebih responsif daripada penggunaan hormon NAA.

\section{DAFTAR PUSTAKA}

Adelina dan Maemunah, 2009. Vigor benih kedelai (Glicine max L.) pada berbagai lama penyimpanan dan invigorasi. J. Agroland. $16(3): 206-212$.

Foild, N., Makkar, H.P dan S., Becker. 2007. The potential of moringa oleifera for agricultural and industrial uses. Mesir, Dar Es Salam.
Krisnadi, A. D. 2015. Kelor Super Nutrisi. Morindo, Jakarta.

Lestari, E. 2011. Peranan zat pengatur tumbuh dalam perbanyakan tanaman melalui kultur jaringan. J. agrobiogen. 7 (1) : 63-68.

Marzuki, M, I. Suliansyah, dan R. Maerni. 2008. Pengaruh NAA pada pertumbuhan bibit nanas (Ananas cornous L. Merr) pada tahap aklimatisasi. J. Jerami. 1 (3) : 111 - 120

Moyo B., Masika, P. J., Hugo, A., and Muchenje V. 2011. Nutritional characterization of Moringa (Moringa oleifera Lam.) leaves. African J. of Biotechnology. 10 (60) : 12925-12933.

Muthukumar, M. Naveena, B. M., vaithiyanatun, S., Sen, A.R. and Sureshkumar, K. 2012. Effect of incorporation of moringa oleifera leaves exctract on quality of ground pork patties. J. of food science and technology. 
Nurcahyani, E. 2014. Khasiat Dahsyat Daun Kelor. Lembar Lanit Indonesia, Jakarta.

Polhaupessy, S. 2014. Pengaruh konsentrasi giberelin dan lama perendaman terhadap perkecambahan biji sirsak (Anonma muricata L.). J. Biopendix. 1(1) : 71-76.

Sari, H.P., C. Hanum dan Charloq. 2014. Daya kecambah dan pertumbuhan mucuna braceta melalui pematahan dormansi dan pemberian zat pengatur tumbuh giberelin $\left(\mathrm{GA}_{3}\right)$. J. Agroekoteknologi. 2 (2) : 630-644.

Saryoko. 2011. Sistem penyediaan benih dan teknologi invigorasi untuk mendukung ketersediaan benih kedelai bermutu di Provinsi Banten. Tesis. Institut Pertanian Bogor.

Tjokrowardojo, A.S., Rosman, R., dan Pradono, D.I. 2009. Pengaruh zat pengatur tumbuh terhadap perkecambahan benih dan pertumbuhan bibit kamarandah (Croto tiglium L.). J. Agrotropika. 14 (2) : 55-60

Weiss, D and N. Ori. 2007. Mechanism of cross talk beetween gibberellin and other hormones.J.Plant physiology, 14 (4) : 12401246. 